\title{
Constitutional and Legal Foundations of Economic Development and the Role of International "Sanctions"
}

\author{
Elena A. Osavelyuk \\ Institute of International Law and Economics named after A.S. Griboedov \\ Moscow, Russia \\ osaveluk@mail.ru
}

\begin{abstract}
On the example of Russia the article demonstrates the relationship between the functioning of constitutional institutions of economic development and state cooperation with the application of sanction measures to its senior officials and heads of state enterprises. It is shown that the unlawful use of such sanctions paralyzes economic development and cooperation, primarily from the part of Western countries in relation to their competitors - the states of the New Silk Road.
\end{abstract}

Keywords: constitutional foundations of economic development, international sanctions, economic sanctions, economic cooperation, the New Silk Road

\section{INTRODUCTION}

The subject of the study is the instrumental use of the socalled sanctions of one state against another through the inclusion in the sanctions list of senior officials who influence the country's economic development and international economic cooperation.

The hypothesis of the study is the assumption that an unfair method is used in modern interstate economic relations against competing states; the essence of this method lies in including into the sanctions list the top state officials (that determine the development vectors of their economy and international economic cooperation), as well as representatives of large budget-forming businesses; this leads to a paralysis of the international economic relations of the state and inhibition of the development of its economy. Moreover, the introduction of new terms: "sanctions for decision-maker", "personal sanctions", "clever sanctions" is just a cover.

\section{METHODS}

In the process of article composing the various general scientific techniques and methods of logical cognition were used. The methods of analysis and synthesis were applied to study the role of senior government officials in determining the development of their economy. The use of formal legal and comparative legal methods made it possible to determine the main provisions of state regulation, as well as the powers of federal bodies of state power, bodies of state power of subjects of the Russian Federation in the field of foreign economic and foreign trade. System-structural, functional, and formal-logical approaches were involved in considering the mechanism of manipulating the instrument of international sanctions in matters of unfair economic competition of states.

\section{DISCUSSION AND RESULTS}

The economic basis is one of the most important components of the constitutional system of the Russian Federation, since its core is constituted by the most important interests of the vast majority of the population: "freedom of economic activity along with the unity of the economic space, free movement of goods, services and financial resources, support for competition" [1]. It is the economic foundations that create the platform for the formation and development of a market economy, the participants of which are independent competing entities, which, in turn, build the foundation for the formation of a democratic state of law.

According to Art. 8 of the Constitution of the Russian Federation the equal recognition and protection of all forms of ownership are also elements of the economic foundations of the constitutional system [2].

For true economic freedom as an ideal prescribed in the Constitution of the Russian Federation, not only domestic but also foreign economic activity is required, which is defined as foreign trade, investment and other activities including industrial cooperation in the field of international exchange of goods, information, work, services, intellectual property activities (rights to obtain them) [3].

This can be confirmed by the Government of the Russian Federation Concept for the Long-Term Socio-Economic Development of the Russian Federation for the Period Until 2020, which states that Russia's foreign economic policy is one of the "most important factors in its socio-economic development, innovative renewal and increasing the competitiveness of the economy, as well as solvation of key social problems" [4]. Due to the special importance of these relations, regulation and state control in the field of foreign economic activity, in compliance with the provisions of the Constitution of the Russian Federation, are entrusted by the Federal Constitutional Law to the Government of the Russian Federation [5]. In order to coordinate foreign trade relations and integrate the state into international economic relations, the Government Commission on Economic Development and Integration was established [6].

The activities of this commission are aimed, in particular, at "protecting the domestic market, including the use of customs and tariff and non-tariff regulation tools; ensuring economic integration; ensuring full membership of Russia in the World Trade Organization and the Organization for Economic Cooperation and Development" [7]. In addition, 
the commission interacts with public organizations and entrepreneurs.

A very important document regulating the area under consideration is the Federal Law "On the Basics of State Regulation of Foreign Trade" [2]. It contains the main provisions on state regulation of foreign trade, methods of state regulation of activities in the field of foreign trade in goods and services, provisions on the powers of federal bodies of state power, bodies of state power of the constituent entities of the Russian Federation and local authorities in the field of foreign trade, and other no less important questions.

Taking into account that Russia is a federal state, it is impossible not to mention the role of its subjects in foreign economic activity, since, although foreign economic relations are exclusively under the jurisdiction of the Russian Federation according to paragraph "l" of art. 71 of the Constitution of the Russian Federation, entities can have foreign economic relations with foreign states and carry them out under the coordination of the Russian Federation (paragraph "o (o)" part 1 of article 72). In development of these constitutional provisions, the Federal Law "On the Coordination of International and Foreign Economic Relations of the Subjects of the Russian Federation" was adopted. In accordance with it, the subjects, within the limits of authority established by the Constitution, federal laws and treaties on the delimitation of objects of competence and authority between federal bodies and bodies of entities, are granted the right to carry out international and foreign economic relations with subjects of foreign federations, administrative territories units of foreign states, as well as to participate in the activities of international organizations within the framework of bodies created specifically for these purposes (Article 1) [9].

Coordination of foreign economic relations of the subjects is regulated by the decrees of the Government of the Russian Federation and should be held in specially created institutional formats and regulations for information exchange [10]. The government makes decisions on the consent of the subjects of international relations with foreign state bodies, [11] establishes the rules for state registration of foreign economic agreements [12].

The participation of subjects in the foreign economic activity of the state is, first of all, important for "achieving the goals of the state policy of regional development and the consistent solution of a number of tasks, the heart of which is the task of identifying and analyzing economic specialization and promising competitive advantages of regions and municipalities" [13, p.88]. All of the above demonstrates the role of state authorities and their officials in the development of the state economy. As a rule, these same people determine the vector of international economic cooperation, make important decisions and participate in international negotiations and business meetings, representing the state. Therefore, their isolation, as well as blocking the state's foreign economic relations, is unfair economic interstate competition aimed at undermining the economic basis of individual states.

The opinion that a state imposes "sanctions" on Russia, then on China, Korea, and other sovereign states has been spread everywhere. Although, in fact, the beautiful nominations: "sanctions for decision-maker", "personal sanctions", "clever sanctions" mask the economically discriminatory steps. This is manifested in the fact that the sanctions list includes members of the government, heads of state authorities and budget-filling enterprises, which is akin to the political and economic blockade of the state. Indeed, in the event of sanctions, neither politicians nor large businessmen can leave their state for forums, exhibitions, conferences, negotiations, their accounts are frozen, and even their partners automatically fall under the sanctions (like two banks of Iranian origin working in Belarus when these sanctions were imposed). As an example, American antiRussian sanctions lists, starting in 2014, regarding the Chairman of the upper house of the Parliament of the Russian Federation V. Matvienko, deputy Chairman of the Government of the Russian Federation D. Rogozin, Advisor to the President of the Russian Federation S. Glazyev, and more than one hundred high-ranking officials, heads of state corporations.

\section{CONCLUSION}

As shown above, the functions and activities of the leaders of state authorities directly determine economic development and cooperation. As a result, the impact on such individuals negatively affects foreign economic policy, relations and the development of both the state's economy and international economic cooperation, and damage to the state's foreign economic and foreign trade activities. This applies not only to Russia. Today, Iran, Korea, Turkey, China and other countries of the Silk Road fall into the cage as the main competitors of the West in the global economic space.

In such a context, these actions contradict the basic principles of international law, since they are nothing more than illegal measures of a discriminatory nature (no matter what words they disguise) that damage business cooperation and economic development, and, accordingly, the economic foundations of the constitutional system of the affected states.

Thus, only by further consolidating joint efforts against unfair economic competition of individual states, by establishing close foreign economic relations, we can resist the aggressive "sanctions" policy currently being implemented, which is aimed primarily at weakening the internal structure of countries.

\section{REFERENCES}

[1] B. S. Jebzeev, Man, people, state in the constitutional system of the Russian Federation, 2-nd ed., M.: Prospekt, 2013 (in Russian).

[2] The Constitution of the Russian Federation (Konstitucija Rossijskoj Federacii) [in Russian].

[3] Federal law "On export control," dated 18.07.1999, No. 183-FZ (as amended on 13.07.2015), Collection of legislation of the Russian Federation, No. 30, Art. 3774, 26.07.1999 (in Russian).

[4] Decree of the Government of the Russian Federation dated 17.11.2008, 2008, No. 1662-r (as amended on 28 September, 2018) "On the Concept of Long-Term Socio-Economic Development of the Russian Federation for the Period Until 2020," Collection of Legislation of 
the Russian Federation, No. 47, Art. 5489, 24.11.2008 (in Russian).

[5] Federal constitutional law of 17.12.1997, No. 2FKZ (as amended on 12/28/2016) "On the Government of the Russian Federation," Meeting of the legislation of the Russian Federation, No. 51, Art. 5712, 22.12.1997 (in Russian).

[6] Decree of the Government of the Russian Federation dated 30.12.2009, No. 1166, "On the Governmental Commission for Economic Development and Integration" (as amended), Meeting of the legislation of the Russian Federation, No. 3, Art. 303, 18.01.2010 (in Russian).

[7] A. B. Smushkin, Commentary on the Federal Constitutional Law dated 17.12.1997, No. 2-FKZ, "On the Government of the Russian Federation" (itemized), ATP Consultant Plus, 2014 (in Russian).

[8] Federal Law dated 08.12.2003, No. 164-FZ (as amended on 01.05.2019), "On the Basics of State Regulation of Foreign Trade Activity", Collection of Legislation of the Russian Federation, 15.12.2003, No. 50, Art. 4850 (in Russian).

[9] Federal Law dated 04.01.1999, No. 4-FZ (as amended on 13.07.2015), "On Coordination of International and Foreign Economic Relations of the Subjects of the Russian Federation", Vedomosti of the Federal Assembly of the Russian Federation, No. 2, 01.11.1999 (in Russian).

[10] Decree of the Government of the Russian Federation dated 15.04.2014, No. 330, "On approval of the state program of the Russian Federation Development of foreign economic activity", Collection of legislation of the Russian Federation, No. 18, Art. 2174, 2014 (in Russian).

[11] Decree of the Government of the Russian Federation dated 01.02.2000, No. 91, "On the adoption by the Government of the Russian Federation of decisions on consent to the implementation by the constituent entities of the Russian Federation of international and foreign economic relations with state authorities of foreign states", Collection of legislation of the Russian Federation, No. 6, Art. 771, 2000 (in Russian).

[12] Decree of the Government of the Russian Federation dated 24.07.2000, No. 552, "On the Approval of the Rules for State Registration of Agreements on the Implementation of International and Foreign Economic Relations Concluded by State Authorities of the Subjects of the Russian Federation", Collection of Legislation of the Russian Federation, No. 31, Art. 3293, 2000 (in Russian).

[13] I. V. Logvinova, Coordination of international and foreign economic relations of the constituent entities of the Russian Federation: monograph, MGIMO (University) of the Ministry of Foreign Affairs of the Russian Federation, Department Legal basis of management, Moscow: MGIMO University, 2018 (in Russian). 